\title{
Coenzyme Q10 Supplementation as an Adjuvant Therapy Potentially Increase Serum Superoxide Dismutase Levels in Acne Vulgaris Patients
}

\author{
Carissa Adriana*(D), Asih Budiastuti, Kabulrachman Kabulrachman, Retno Indar Widayati, Puguh Riyanto, Muslimin Muslimin
}

Department of Dermatovenereology, Faculty of Medicine, Diponegoro University, Semarang, Indonesia

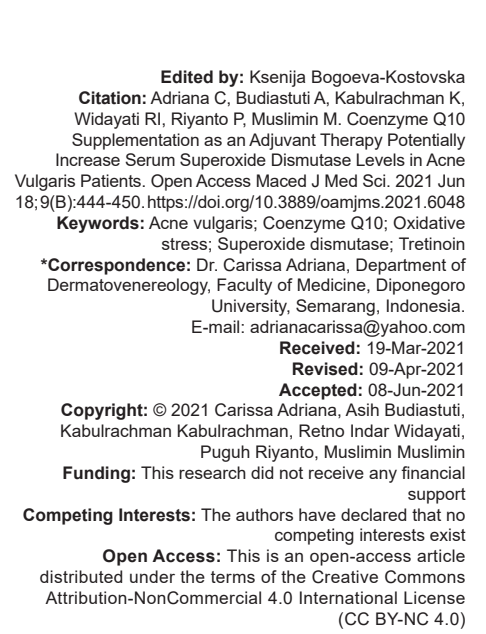

\section{Abstract}

BACKGROUND: Acne vulgaris (AV) is a chronic inflammatory disease in the pilosebaceous unit. Recent research has begun to focus on the essential relationship between oxidative stress and the pathogenesis of AV. The use of antioxidants like coenzyme Q10 (CoQ10) that has various advantages as adjuvant therapy is expected to be beneficial for AV.

AIM: The study was aimed to analyze the effect of CoQ10 supplementation on serum SOD levels and the severity of $\mathrm{AV}$ patients.

METHODS: A double blind-randomized controlled trial was carried out on 36 patients with AV and classified according to severity degree of AV. These patients were randomly divided into two groups (treatment group with tretinoin $0.025 \%$ cream and once-daily supplementation of CoQ10 $100 \mathrm{mg}$ tablet; and placebo group with tretinoin $0.025 \%$ cream and once-daily placebo tablet). Response to treatment was based on serum superoxide dismutase (SOD) level and AV severity degree.

RESULTS: Administration of CoQ10 to AV patients significantly increase serum SOD level $(p=0.008)$ and improves the severity of AV after 8 weeks $(p=0.008)$.

CONCLUSION: COQ10 supplementation can increase serum SOD levels and improve the severity of AV.

\section{Introduction}

Acne vulgaris (AV) is a chronic inflammatory disease in the pilosebaceous unit and is more common in adolescents but can continue into adulthood [1], [2], [3]. Based on the Indonesian Dermatology Study Group in 2013, AV ranks $3^{\text {rd }}$ most of the number of visitors to the Department of Dermatovenereology Hospitals and Clinics in Indonesia [4]. Pathogenesis of AV involves four main components, as well as excessive sebum production, abnormal keratinization of the follicle, inflammation, and bacterial colonization of Propionibacterium acnes ( $P$. acnes) [1], [2], [3]. Recent research has begun to focus on the essential relationship between oxidative stress and pathogenesis of AV through the formation of reactive oxygen species (ROS) and lipid peroxide, where several mechanisms and molecular pathways occur, namely activation of toll-like receptors (TLRs), peroxisome proliferator-activated receptors, natural immune system, and mechanistic target of rapamycin pathways [5], [6], [7], [8].
The skin has developed a complex and specific endogenous anti-oxidative mechanism to overcome problems that arise due to ROS through enzymatic antioxidants, namely superoxide dismutase (SOD), catalase (CAT), and glutathione peroxidase (GSH-Px), which play a role in neutralizing ROS and preventing oxidative damage to cells and tissues [9], [10], [11]. SOD is an important enzymatic antioxidant that acts as the first line of defense and is considered a key antioxidant. SOD scavenges free radical anion superoxide $\left(\mathrm{O}^{2-}\right)$ and reduces their toxicity. SOD converts highly reactive $\mathrm{O}^{2-}$ to hydrogen peroxide, which by de-mutating $\mathrm{O}^{2-}$, SOD prevents the release of iron ions and the formation of harmful ROS such as hydroxyl radicals $\left(\mathrm{OH}^{-}\right)$. SOD also protects vascular nitric oxide (NO) signaling by preventing its reaction with $\mathrm{O}^{2-}$ and preventing the formation of peroxynitrite, which is a dangerous reactive nitrogen species [3], [12].

The classification of AV severity in Indonesia uses the Lehmann grading system recommended by the Indonesian Acne Expert Meeting in 2015 based on mild, moderate, and severe by calculating the total amount from comedones, papules/pustules, and 
nodules/cysts [13]. Topical tretinoin is the first choice as a standard therapy of AV [14]. Considering the important role of oxidative stress in the pathogenesis of $\mathrm{AV}$, the use of antioxidants as adjuvant therapy is beneficial for AV [7], [15], [16]. Adjuvant therapy is a treatment that is given together with the main therapy to accelerate healing or improve skin conditions during treatment [13], [14]. The concept of antioxidant therapy aims to strengthen the endogenous antioxidant defenses against oxidative stress more effectively [13], [17], [18].

Coenzyme Q10 (CoQ10) or ubiquinone is a liposoluble compound which is a non-enzymatic endogenous antioxidant that works as the most essential cofactor and has various advantages such as its activity in producing cellular energy, increasing the work capacity of enzymatic antioxidants in taking free radicals, having anti-inflammation through antioxidant activity, inhibits the initiation and propagation phase of lipid peroxide, and regenerates other antioxidants such as tocopherol and ascorbate[18],[19],[20],[21],[22],[23].Therecommended systemic dose of CoQ10 is 30-90 mg/day, where clinical effects take up to 8 weeks [24], [25], [26]. So far, there has never been a research article that discusses the effect of oral CoQ10 supplementation on SOD levels in AV patients. Therefore, this research to study the effect of CoQ10 on serum SOD levels in AV patients.

\section{Methods}

\section{Research design}

This study was carried out for a period from December 2019 to February 2020. Thirty-six women clinically diagnosed with $\mathrm{AV}$, who attended the outpatient Department of Dermatology and Venereology, Dr. Kariadi Hospital, were enrolled in this study. Before initiation of the study, each subject was informed about the aim of the study and signed informed consent. Ethical approval for this study was obtained from (376/EC/KEPK-RSDK/2019). The inclusion criteria were: Mild to moderate-severe AV patients, female, age 20-40 years, normal body mass index, mild to normal stress level (assessed by Beck's Depressed Inventory); not taking drugs (antibiotics, anti-inflammatory, betablocker antihypertensive, statin antihyperlipidemic, warfarin, other vitamins, and antioxidants) in the past 1 month; not pregnant and breastfeeding; not smoking, and are willing to take part in this study to completion, while exclusion criteria include: Patients whose blood samples cannot be collected (due to technical problems) and patients who suddenly refused while taken the blood sample.

The study was performed with 36 patients randomly allocated into two groups.

$$
\mathrm{N} 1=\mathrm{n} 2=2\left(\frac{(1.96+0.84) \times 0.508}{(11.234-10.726)}\right) 2=16
$$

The minimum sample required is calculated as 16 , to anticipate a non-response or drop-out percentage as $10 \%, 16+(10 \% \times 16)=17.6$. Then final sample $=18$ samples for this study.

The first group consists of 18 patients, treated with tretinoin $0.025 \%$ cream and CoQ10 $100 \mathrm{mg}$ tablet/ day orally; the second group consists of 18 patients, treated with tretinoin $0.025 \%$ cream and placebo tablet/ day orally. The use of sunscreen cream of SPF 30 was suggested during the study period. The diagnosis of AV was based on the total lesion count of comedones, papules, pustule nodules, and cysts according to the Lehmann grading system of AV severity degree. The duration required for each patient to complete the course of the treatment was 8 weeks, clinical and laboratory assessment would be carried out at baseline and by the end of this period. Side effects would be looked for by asking the patients about any abnormal effect that appeared throughout the whole course of treatment.

\section{Sample analysis}

Blood samples for SOD3 analysis were collected between December 2019 and February 2020. Blood samples were collected $3 \mathrm{ml}$ from venipuncture allow samples to clot for $2 \mathrm{~h}$ at room temperature or overnight at $4^{\circ} \mathrm{C}$ before centrifuge for $15 \mathrm{~min}$ at $1000 \times \mathrm{g}$ at $2-8^{\circ} \mathrm{C}$. SOD3 serum was examined with enzyme-linked immunosorbent assay (ELISA) Elabscience®.

\section{Statistical analysis}

The data obtained were processed with the Statistical Package for Social Science program for Windows. Paired t-test, Wilcoxon, Mann-Whitney, McNemar, and Chi-square would be used to compare between the different groups' concerning and posttreatment values $p \leq 0.05$ is considered as a significant change. Spearman correlation test would be used to compare between SOD serum level and severity of AV. The degree of relationship is expressed by the magnitude of the correlation coefficient. The intention to treat analysis was used in this study

\section{Results}

This study involved 36 research subjects divided into 2 groups: The treatment group with CoQ10 
( $n=18$ subjects) and the control group with placebo ( $n=18$ subjects). The number of research subjects at the end of the study is the same as at the beginning of the study, no research subjects were found to experience drop-outs, as shown in Figure 1.

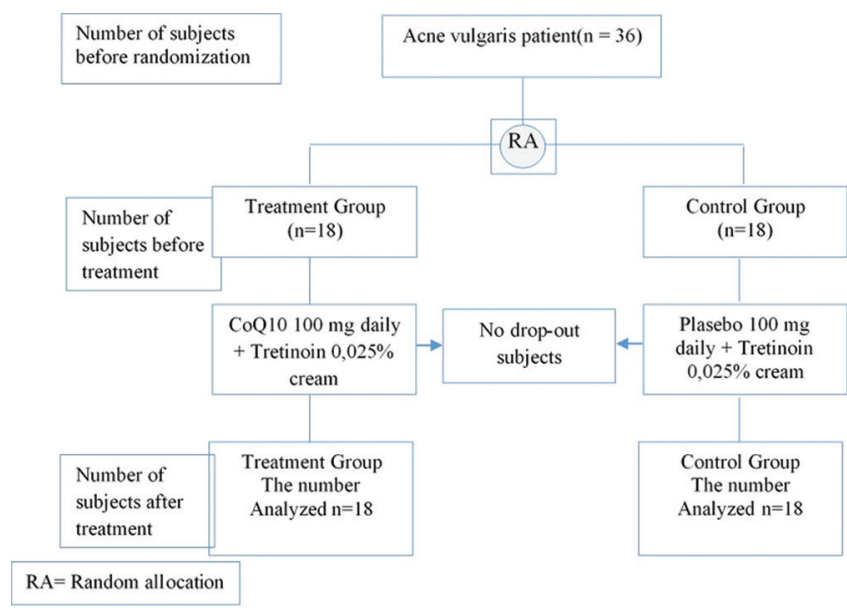

Figure 1: Diagram of the number of subjects in the treatment and control group in the study of the effect of coenzyme Q10 on superoxide dismutase serum levels and severity of acne vulgaris at Dr. Kariadi General Hospital Medical Center in December 2019February $2020(n=36)$

Table 1 shows that the mean age of the study subjects in the treatment group was $25.9 \pm 4.52$ years with the youngest age being 21 years and the oldest was 33 years. The mean age of the study subjects in the control group was older than the treatment group which was $26.5 \pm 5.82$ years with the youngest age being 20 years and the oldest was 40 years. Statistical test results showed that the mean age difference of the study subjects between the treatment group and the control group was not significant ( $p=0.9$; MannWhitney test). The type of occupations of the research subjects in the treatment group was students (44.4\%), while in the control group, the majority were office employees (33.3\%). Statistical test results showed that this difference was not significant ( $p=0.1$; Fisher's exact test). In the treatment group that most of the study subjects had no sun exposure (55.6\%), whereas, in the control group, the number of subjects without sun exposure was as much as subjects with sun exposure (each 50\%). Statistical test results showed

Table 1: Characteristics of study subjects in the research group effect of CoQ10 on SOD serum levels and severity of AV at Dr. Kariadi General Hospital Medical Center Semarang in December 2019-February $2020(n=36)$

\begin{tabular}{llll}
\hline Characteristics & Group & $\mathrm{p}$ \\
\cline { 2 - 3 } & Treatment $(\mathrm{n}=18)$ & Control $(\mathrm{n}=18)$ & \\
\hline Age; mean \pm SD; median (min-max) & $25.9 \pm 4.52 ; 25$ & $26.5 \pm 5.82 ; 25$ & $0.9^{*}$ \\
& $(21-33)$ & $(20-40)$ & \\
Type of occupations; $\mathrm{n}(\%)$ & & & \\
Doctor & $7(38.9)$ & $4(22.2)$ & $0.1^{\S}$ \\
$\quad$ University student & $8(44.4)$ & $5(27.8)$ & \\
Office employee & $1(5.6)$ & $6(33.3)$ & \\
Midwife. nurse & $2(11.1)$ & $1(5.6)$ & \\
$\quad$ Housewife & $0(0.0)$ & $2(11.1)$ & \\
Sun exposure & $10(55.6)$ & $9(50.0)$ & 0.7 \\
$\quad$ None & $8(44.4)$ & $9(50.0)$ & \\
Exist & &
\end{tabular}

that the difference in the distribution of sun exposure between the treatment and control groups was not significant ( $p=0.7 ; x^{2}$ test).

Figure 2 shows that in the treatment group, there was a significant increase in serum SOD levels from before to after treatment ( $p<0.001$; Wilcoxon test), whereas in the control group, there was only a small increase that was not significant $(p=0.7)$.

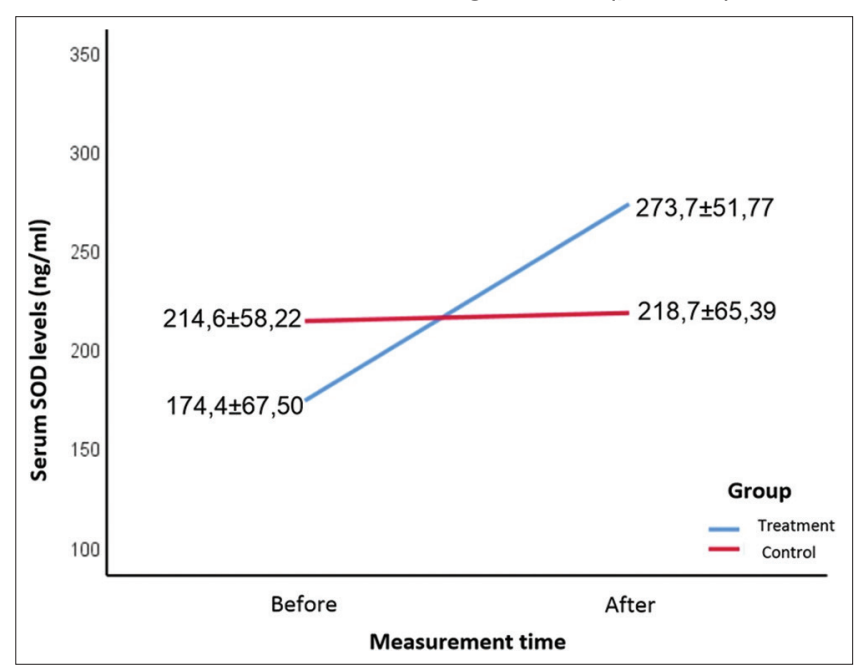

Figure 2: Changes in serum SOD levels from before to after treatment in the study of the effect of coenzyme Q10 on superoxide dismutase serum levels and severity of acne vulgaris at Dr. Kariadi General Hospital Medical Center Semarang in December 2019-February $2020(n=36)$

Table 2 shows that the serum SOD levels before treatment in the treatment group which was $174.4 \pm 67.50 \mathrm{ng} / \mathrm{ml}$ were lower than the control group, which was $214.6 \pm 58.22 \mathrm{ng} / \mathrm{ml}$, but statistically, the difference was not significant ( $p=0.06$; unpaired t-test). Serum SOD levels after treatment in the treatment group that was $273.7 \pm 51.77 \mathrm{ng} / \mathrm{ml}$ were significantly higher than the control group, which was $218.7 \pm$ $65.39 \mathrm{ng} / \mathrm{ml}$ ( $p=0.008$; unpaired t-test). Delta SOD serum treatment group that is $99.3 \pm 63.65 \mathrm{ng} / \mathrm{ml}$ was significantly higher than the control group, which was $4.1 \pm 54.00 \mathrm{ng} / \mathrm{ml}(\mathrm{p}<0.001$; unpaired t-test).

Table 2: Serum SOD levels in the treatment and control groups in the study of the effect of COQ10 on SOD serum levels and severity of AV at Dr. Kariadi General Hospital Medical Center Semarang in December 2019-February 2020 ( $n=36)$

\begin{tabular}{|c|c|c|c|}
\hline \multirow{3}{*}{ Measurement time } & \multicolumn{2}{|c|}{ Serum SOD levels $(\mathrm{ng} / \mathrm{ml})$ in group: } & \multirow{3}{*}{$\mathrm{p}^{*}$} \\
\hline & Treatment $(n=18)$ & Control $(n=18)$ & \\
\hline & $\begin{array}{l}\text { Mean } \pm \text { SD; Median } \\
\text { (Min-Max) }\end{array}$ & $\begin{array}{l}\text { Mean } \pm \text { SD; Median } \\
(\text { Min-Max) }\end{array}$ & \\
\hline Before & $\begin{array}{l}174.4 \pm 67.5 ; 167.4 \\
(81.5-315.8)\end{array}$ & $\begin{array}{l}214.6 \pm 58.22 ; 196.2 \\
(147.7-346.8)\end{array}$ & 0.06 \\
\hline After & $\begin{array}{l}273.7 \pm 51.77 ; 270.9 \\
(147.8-364.8)\end{array}$ & $\begin{array}{l}218.7 \pm 65.39 ; 212.9 \\
(116.5-355.6)\end{array}$ & 0.008 \\
\hline Delta & $\begin{array}{l}99.3 \pm 63.65 ; 76.1 \\
(13.4-235.2)\end{array}$ & $\begin{array}{l}4.1 \pm 54.00 ; 14.0 \\
(-118.2-77.7)\end{array}$ & $<0.001$ \\
\hline $\mathrm{p}^{\star *}$ before versus after & $<0.001$ & 0.7 & \\
\hline
\end{tabular}

Table 3 shows the severity of AV based on the Lehmann grading system in the treatment and control groups. Statistical test results showed that the change in the severity of AV in the treatment 
Table 3: Severity degree of AV in the study group in the study of the effect of CoQ10 on SOD serum levels and severity of AV at Dr. Kariadi General Hospital Medical Center Semarang in December 2019-February 2020 (n = 36)

\begin{tabular}{llll}
\hline Severity degree of AV & \multicolumn{2}{l}{ Group $(\%)$} & $\mathrm{p}$ \\
\cline { 2 - 3 } & Treatment $(\mathrm{n}=18)$ & Control $(\mathrm{n}=18)$ & \\
\hline Before/pre-treatment & $6(33.3)$ & $6(33.3)$ & 1.0 \\
$\quad$ Mild & $6(33.3)$ & $6(33.3)$ & \\
$\quad$ Moderate & $6(33.3)$ & $6(33.3)$ & \multirow{2}{*}{$0.3^{\S}$} \\
$\quad$ Severe & $14(77.8)$ & $10(55.6)$ & \\
After/post-treatment & $4(22.2)$ & $7(38.9)$ & $1(5.6)$ \\
$\quad$ Mild & $0(0.0)$ & & \\
$\quad$ Moderate & Sever &
\end{tabular}

group was significant ( $p=0.008$; McNemar's test), while the change in the severity of $A V$ in the control group was not significant ( $p=0.05$; McNemar's test). The distribution of the severity of $A V$ before treatment between the treatment groups was the same as the control group ( $p=1,01 x^{2}$ test). After treatment in both the treatment and control groups, the most was a mild degree of $\mathrm{AV}$, the next was moderate, and there was only 1 subject with every degree of AV in the control group. Statistical test results showed that the difference in the distribution of the severity of AV after treatment between the treatment and control groups was not significant ( $p=0.3$; Fisher's exact test).

Table 4 shows that the mean serum SOD levels before the lowest treatment was in the group with severe severity of AV which was $181.9 \pm$ $65.56 \mathrm{ng} / \mathrm{ml}$, while the highest was in the mild AV group which was $212.3 \pm 71,96 \mathrm{ng} / \mathrm{ml}$. Statistical test results showed that differences in serum SOD levels based on $\mathrm{AV}$ degrees before treatment were not significant $(p=0.5$; one-way ANOVA test). The highest serum SOD level after treatment was in the group with mild AV severity that was $260.2 \pm 63.2 \mathrm{ng} / \mathrm{ml}$ and the lowest was in the group with severe AV severity that was $209.8 \pm 0.00 \mathrm{ng} / \mathrm{ml}$. Statistical test results also showed differences in serum SOD levels based on the severity of AV when after test was not significant ( $p=0.06$; oneway ANOVA test).

Table 4: Serum SOD levels based on the severity of AV before and after treatment in the study of the effect of CoQ10 on SOD serum levels and severity of AV at Dr. Kariadi General Hospital Medical Center Semarang in December 2019-February 2020 $(n=36)$

\begin{tabular}{ll}
\hline Severity degree of AV & $\begin{array}{l}\text { Serum SOD levels }(\mathrm{ng} / \mathrm{ml}) \text { Mean } \pm \\
\text { standard deviation; Median (Min-Max) }\end{array}$ \\
\hline Before treatment & \\
$\quad$ Mild $(\mathrm{n}=12)$ & $212.3 \pm 71.96 ; 228.2(87.8-302.4)$ \\
$\quad$ Moderate $(\mathrm{n}=12)$ & $189.2 \pm 59.80 ; 175.6(83.0-315.80)$ \\
$\quad$ Severe $(\mathrm{n}=12)$ & $181.9 \pm 65.56 ; 172.7(81.5-346.80)$ \\
After treatment & $260.2 \pm 63.2 ; 268.3(116.5-364.8)$ \\
$\quad$ Mild $(\mathrm{n}=24)$ & $218.9 \pm 62.85 ; 222.7(125.7-338.5)$ \\
$\quad$ Moderate $(\mathrm{n}=11)$ & $209.8 \pm 0.00 ; 209.8(209.8-209.8)$ \\
$\quad$ Severe $(\mathrm{n}=1)$ &
\end{tabular}

Table 5 shows that the highest delta SOD was $235.21 \mathrm{ng} / \mathrm{ml}$. It was found in the subjects of the treatment group with a mild degree of severity before and after treatment. The lowest delta SOD was -118.17 $\mathrm{ng} / \mathrm{ml}$ which was found in the subjects of the treatment group with a severe severity before treatment and a moderate severity after treatment.

Table 5: Delta data of serum SOD levels in each study subject based on the severity of $A V$ and the research group in the study of the effect of CoQ10 on SOD levels and serum AV severity at Dr. Kariadi General Hospital Medical Center Semarang in December 2019-February $2020(n=36)$

\begin{tabular}{|c|c|c|c|}
\hline \multicolumn{2}{|c|}{ Severity degree of AV } & \multirow[t]{2}{*}{ Group } & \multirow[t]{2}{*}{ Delta serum SOD levels (ng/ml) } \\
\hline Before treatment & After treatment & & \\
\hline Mild & Mild & Treatment & 235.21 \\
\hline Mild & Mild & Treatment & -40.41 \\
\hline Mild & Mild & Control & 164.7 \\
\hline Mild & Mild & Control & 9.26 \\
\hline Mild & Mild & Treatment & 19.36 \\
\hline Mild & Mild & Treatment & 29.94 \\
\hline Mild & Mild & Treatment & -82.44 \\
\hline Mild & Mild & Control & 130.05 \\
\hline Mild & Mild & Treatment & 76.81 \\
\hline Mild & Mild & Control & 34.64 \\
\hline Mild & Mild & Control & 48.99 \\
\hline Mild & Mild & Control & 13.44 \\
\hline Moderate & Mild & Control & -31.23 \\
\hline Moderate & Mild & Control & 34.83 \\
\hline Moderate & Mild & Control & 15.26 \\
\hline Moderate & Moderate & Treatment & 9.31 \\
\hline Moderate & Mild & Treatment & 162.44 \\
\hline Moderate & Moderate & Control & 22.65 \\
\hline Moderate & Mild & Control & 67.79 \\
\hline Moderate & Mild & Treatment & 92.93 \\
\hline Moderate & Moderate & Control & 12.68 \\
\hline Moderate & Moderate & Treatment & 74.4 \\
\hline Moderate & Moderate & Control & -55.23 \\
\hline Moderate & Mild & Control & 156.74 \\
\hline Severe & Mild & Treatment & 77.73 \\
\hline Severe & Moderate & Treatment & 71.9 \\
\hline Severe & Mild & Treatment & 200.29 \\
\hline Severe & Moderate & Treatment & 118.15 \\
\hline Severe & Moderate & Control & 40.29 \\
\hline Severe & Moderate & Treatment & 77.7 \\
\hline Severe & Mild & Control & -30.98 \\
\hline Severe & Moderate & Treatment & 66.93 \\
\hline Severe & Mild & Control & 66.29 \\
\hline Severe & Mild & Control & 64.46 \\
\hline Severe & Moderate & Treatment & -118.17 \\
\hline Severe & Severe & Treatment & 24.19 \\
\hline
\end{tabular}

Table 6 shows a significant correlation between serum SOD levels after treatment with the severity of AV after treatment ( $p=0.04$; Spearman's correlation test). The analysis also shows the relationship between serum SOD levels before and delta serum SOD levels with a degree of AV severity are not significant.

Table 6: Relationship between the severity of AV with serum SOD levels and delta in the study of the effect of CoQ10 on the level of SOD serum and severity of AV at Dr. Kariadi General Hospital Medical Center Semarang in December 2019-February $2020(n=36)$

\begin{tabular}{|c|c|c|c|c|c|}
\hline $\begin{array}{l}\text { Severity } \\
\text { degree of AV } \\
\text { and serum } \\
\text { SOD levels }\end{array}$ & $\begin{array}{l}\text { Severity degree } \\
\text { of AV before } \\
\text { treatment }\end{array}$ & $\begin{array}{l}\text { Severity } \\
\text { degree of AV } \\
\text { after treatment }\end{array}$ & $\begin{array}{l}\text { Serum SOD } \\
\text { levels before } \\
\text { treatment }\end{array}$ & $\begin{array}{l}\text { Serum SOD } \\
\text { levels after } \\
\text { treatment }\end{array}$ & $\begin{array}{l}\text { Delta } \\
\text { serum } \\
\text { SOD levels }\end{array}$ \\
\hline $\begin{array}{l}\text { Severity } \\
\text { degree of } \\
\text { AV before } \\
\text { treatment }\end{array}$ & 1.0 & $\begin{array}{l}0.51 \\
(p=0.001)\end{array}$ & $\begin{array}{l}-0.25 \\
(p=0.1)\end{array}$ & $\begin{array}{l}-0.11 \\
(p=0.5)\end{array}$ & $\begin{array}{l}0.11 \\
(p=0.5)\end{array}$ \\
\hline $\begin{array}{l}\text { Severity } \\
\text { degree of AV } \\
\text { after treatment }\end{array}$ & - & 1.0 & $\begin{array}{l}-0.11 \\
(p=0.52)\end{array}$ & $\begin{array}{l}-0.33 \\
(p=0.04)\end{array}$ & $\begin{array}{l}-0.16 \\
(p=0.3)\end{array}$ \\
\hline $\begin{array}{l}\text { Serum SOD } \\
\text { levels before } \\
\text { treatment }\end{array}$ & - & - & 1.0 & $\begin{array}{l}0.33 \\
(p=0.04)\end{array}$ & $\begin{array}{l}0.11 \\
(p=0.5)\end{array}$ \\
\hline $\begin{array}{l}\text { Serum SOD } \\
\text { levels after } \\
\text { treatment }\end{array}$ & - & - & - & 1.0 & $\begin{array}{l}-0.53 \\
(p=0.001)\end{array}$ \\
\hline
\end{tabular}




\section{Discussion}

This study was a randomized controlled clinical trial, in which subjects in mild, moderate, and severe AV patients have treated with CoQ10 supplementation $1 \mathrm{mg} \times 100 \mathrm{mg}$ in the treatment group and placebo $1 \mathrm{mg} \times 100 \mathrm{mg}$ for 8 weeks in the control group. Researchers used the pre-test and post-test design and double-blind method. Based on the data of the characteristics of the research subjects, all subjects in the treatment and control group were women (100\%), according to a study shows that two-thirds of patients who go to a dermatologist with $\mathrm{AV}$ complaints are women [27]. All subjects were in the normalized weight category $(100 \%)$ and examination with the Beck's Depression Inventory questionnaire, none of the subjects experienced depression (100\%) and obtained that there are differences in age, type of occupations, and exposure to sunlight. The absence of significant differences in the characteristics of research subjects between the treatment and control groups shows that the potential variable characteristics as confounding variables can be controlled.

Serum SOD levels after treatment in the treatment group were significantly higher than in the control group ( $p=0.008$; unpaired t-test), whereas the delta serum SOD treatment group was significantly higher than the control group $(p<0.001$; unpaired t-test). It can be concluded that there is an improvement in serum SOD levels in the treatment group compared to the control group, this is because CoQ10 supplementation can increase the enzymatic endogenous antioxidant activity which is the first-line defense system, namely SOD [2], [3]. A meta-analysis is of 13 clinical randomized controlled trials of 912 potential citations found to be eligible by Jorat et al. [28] showed that CoQ10 supplementation significantly increased SOD levels as a marker of inflammation and oxidative stress in coronary arterial disease patients compared control group, where it has been previously stated that there is a relationship between oxidative stress and pathogenesis of AV [4]. Research conducted by Zhang et al. [29] also found that the use of CoQ10 significantly reduces the production of UV-induced ROS as a marker of oxidative stress.

The severity of $A V$ in this study found a clinical improvement in decreasing the severity of $\mathrm{AV}$ where most AV sufferers were in mild degrees and no more severe AV degrees were found after therapy in the treatment group. There was also a clinical improvement in the severity of $\mathrm{AV}$ in the control group, whereas most AV sufferers were in mild degrees, but patients with severe $A V$ were still found, although the results were not significant ( $p=0.05$; McNemar's test). Research subjects with mild degrees in the treatment and control groups, although still in a mild degree, decreased in the number of non-inflammatory and inflammatory lesions following the Lehmann grading system. This shows that there is a clinical improvement in the degree of $\mathrm{AV}$ greater in the treatment group compared to the control group. Several new studies have shown that AV sufferers may experience increased oxidative stress and have decreased levels of endogenous antioxidants in the blood. This results in higher levels of ROS produced by neutrophils, wherein ROS participates in the development of inflammatory AV. Therefore, it is mentioned that antioxidant supplements may be a valuable adjuvant in AV [30]. CoQ10 therapy as an antioxidant can reduce the production of free radicals by increasing the activity of endogenous antioxidants, regenerating Vitamin $E$, reducing DNA damage and oxidative damage in the mitochondria [31]. Differences in severity distribution $\mathrm{AV}$ after treatment between the treatment and control groups were not significant, this could be due to all subjects being given a topical retinoid, that is, tretinoin $0.025 \%$, which had a role in $\mathrm{AV}$ therapy. Tretinoin works to normalize desquamation by reducing the proliferation of keratinocytes and blocking several important inflammatory pathways in AV, namely TLR's, leukocyte migration, and the AP-1 pathway, which by suppressing TLR's expression can reduce the release of inflammatory cytokines and NO, also inhibit inflammation. Randomized controlled trials have proven that topical tretinoin as monotherapy significantly reduces inflammatory lesions comparable to those in non-inflammatory lesions. Research conducted by Leyden et al. in 2017 states that there was a significant clinical improvement in inflammatory AV and decreased severity of AV after monotherapy with topical tretinoin for $12-15$ weeks [32].

This study shows that there is no significant correlation between serum SOD levels before treatment with $\mathrm{AV}$ severity, but there is a significant correlation between serum SOD levels after treatment with AV severity. The mean serum SOD level before treatment was the lowest in the severe AV group, which was $181.9 \pm 65.56 \mathrm{ng} / \mathrm{ml}$, while the highest was in the mild AV group which was $212.3 \pm 71.96 \mathrm{ng} / \mathrm{ml}$. Serum SOD levels after the highest treatment were in the mild AV group, which was $260.2 \pm 63.2 \mathrm{ng} / \mathrm{ml}$ and the lowest was in the severe AV group, which was $209.8 \pm$ $0.00 \mathrm{ng} / \mathrm{ml}$. Research conducted by Perihan et al. states that SOD levels are decreased in patients with severe AV compared with mild and moderate AV $(p<0.05)$, however, the correlation between serum SOD levels and the severity of $A V$ is not significant. This can be due to an increase in antioxidant enzymes in inflammation as in AV, possibly inducing subunits of each oxidative biomarker, but the occurrence of severe inflammation can also cause decreased antioxidant enzyme activity [33]. Other research conducted by Al-Shobaili et al. [34], in as many as 50 serum samples of subjects with $A V$, showed that SOD decreased significantly with the increase in severity of AV. Decreased serum SOD levels indicate that in $\mathrm{AV}$, there is a disturbance in the antioxidant balance which causes an increase in ROS 
levels, thus contributing to an increase in oxidative stress. Besides, this finding also shows that oxidative stress increases in $\mathrm{AV}$ along with an increase in the severity of the disease.

\section{Conclusion}

CoQ10 supplementation as adjuvant therapy for AV can increase serum SOD levels and improve the severity of AV compared with placebo supplementation. Future studies are necessary to the understanding of the relationships between SOD and other antioxidant enzymes such as GSH-Px, CAT, malondialdehyde as indicators of oxidative stress, air pollution, and proinflammatory factors may improve our ability to develops interventions aimed to decrease oxidative stress

\section{References}

1. Gaber MA, Dawood AA, MahmoudAA. Oxidants and antioxidants role in acne vulgaris. Menoufia Med J. 2014;27:465-8. https:// doi.org/10.4103/1110-2098.141728

2. Mills $\mathrm{OH}$, Criscito MC, Schlesinger TE, Verdicchio R, Szoke E. Addressing free radical oxidation in acne vulgaris. J Clin Aesthet Dermatol. 2016;9(1):25-30.

PMid:26962389

3. El Garem YF, Ahmed RA, Ragab MA, AbouZeid AA. Study of oxidative stress in different clinical severities of acne vulgaris. Egypt J Dermatol Venerol. 2014;34:53-7. https://doi. org/10.4103/1110-6530.137313

4. Tangheti EA. The role of inflammation in the pathology of acne. J Clin Aesthet Dermatol. 2013;6(9):27-35.

PMid:24062871

5. Marzano AV, Ortega-LoayzaAG, Heath M, Morse D, Genovese G, Cugno M. Mechanisms of inflammation in neutrophil-mediated skin diseases. Front Immunol. 2019;10:1059. https://doi. org/10.3389/fimmu.2019.01059

PMid:31139187

6. Kardeh S, Moein SA, Namazi MR, Kardeh B. Evidence for the important role of oxidative stress in the pathogenesis of acne. GMJ. 2019;8:e1291.

7. Zouboulis CC, Bettoli V. Management of severe acne. Br J Dermatol. 2015;172(S1):27. https://doi.org/10.1111/bjd.13639. PMid:25597508

8. Cong $\mathrm{T}$, Hao $\mathrm{D}$, Wen $\mathrm{X}$, Li XH, He G, Jiang X. From pathogenesis of acne vulgaris to anti acne agents. Arch Dermatol Res. 2019;311(5):337-49. https://doi.org/10.1007/ s00403-019-01908-x PMid:30859308

9. Baumann L, Saghari S. Antioksidan. In: Baumann L, Saghari S, Weisberg E, editors. Cosmetic Dermatology. $2^{\text {nd }}$ ed. New York: McGraw-Hill; 2009.

10. Baek J, Lee MG. Oxidative stress and antioxidant strategies in dermatology. Redox Rep. 2016;21(4):164-9. https://doi.org/10.1 179/1351000215y.0000000015

\section{PMid:26020527}

11. Rinnerthaler M, Bischof J, Streubel MK, Trost A, Richter K Oxidative stress in aging human skin. Biomolecules. 2015;5(2):545-89. https://dx.doi.org/10.3390\%2Fbiom5020545 PMid:25906193

12. Mirończuk-Chodakowska I, Witkowska AM, Zujko ME. Endogenous non-enzymatic antioxidants in the human body. Adv Med Sci. 2018;63(1):68-78. https://doi.org/10.1016/j. advms.2017.05.005 PMid: 28822266

13. Kelompok Studi Dermatologi Kosmetik Indonesia. Indonesian Acne Expert Meeting 2015. Jakarta: Perhimpunan Dokter Spesialis Kulit dan Kelamin Indonesia; 2015.

14. Zaenglein AL, Pathy AL, Schlosser BJ, Alikhan A, Baldwin HE, Berson DS, et al. Guidelines of care for the management of acne vulgaris. J Am Acad Dermatol. 2016;74:945-73. https://doi. org/10.1016/j.jaad.2015.12.037

PMid:26897386

15. Bowe WP, Logan AC. Clinical implications of lipid peroxidation in acne vulgaris: old wine in new bottles. Lipids Health Dis. 2010;9:141. https://dx.doi.org/10.1186\%2F1476-511X-9-141 PMid:21143923

16. Vollmer DL, West VA, Lephart ED. Enhancing skin health: By oral administration of natural compounds and minerals with implications to the dermal microbiome. Int J Mol Sci. 2018;19(10):E3059. https://dx.doi. org/10.3390\%2Fijms 19103059 PMid:30301271

17. Sahib AS, Al-Anbari HH, Raghif AR. Oxidative stress in acne vulgaris: An important therapeutic target. J Mol Pathophysiol. 2013;2:27-31. https://doi.org/10.5455/jmp.20130127102901

18. Varela-LópezA,GiampieriF,BattinoM,QuilesJL.CoenzymeQand its role in dietary therapy against aging. Molecules. 2016;21:373. https://dx.doi.org/10.3390\%2Fmolecules21030373 PMid:26999099

19. Le Quéré S, Lemaire B, Carillon J, Schmitt K. The role of superoxide dismutase (SOD) in skin disorders. A review. Nutrafoods. 2014;13:13-27. https://doi.org/10.1007/ s13749-014-0001-X

20. Zhai J, BoY, Lu Y, Liu C, Zhai L. Effects of coenzyme q10 on markers of inflammation: A systematic review and metaanalysis. PLoS One. 2017;12(1):170-2. https://doi.org/10.1371/ journal.pone.0170172

PMid:28125601

21. Turunen M, Olsson J, Dallner G. Metabolism and function of coenzyme Q. Biochim Biophys Acta 2004;1660(1-2):171-99. https://doi.org/10.1016/j.bbamem.2003.11.012 PMid: 14757233

22. Kagan VE, Quinn PJ. Coenzyme Q: Molecular Mechanism in Health and Disease. New York: CRC Press; 2000

23. Maria T. Alternative Medicine and Control Over the Oxidative Stress. Maldova: Lambert Publishing; 2018.

24. Kim J, Ochoa MT, Krutzik SR, Takeuchi O, Uematsu S, Legaspi AJ, et al.Activation of toll-like receptor 2 in acne triggers inflammatory cytokine responses. J Immunol. 2002;169(3):153541. https://dx.doi.org/10.4049\%2Fjimmunol.169.3.1535 PMid: 12133981

25. Dispenza MC, Wolpert EB, Gilliland KL, Dai JP, Cong Z, Nelson AM, et al. Systemicisotretinoin therapy normalizes exaggerated TLR-2-mediated innate immune responses in acne patients. J Invest Dermatol. 2012;132(9):2198-205. https://doi. org/10.1038/jid.2012.111

PMid:22513780

26. Grange AP, Chéreau C, Raingeaud J, Nicco C, Weill B, 
Dupin N, et al. Production of superoxide anions by keratinocytes initiates $P$. acnes-induced inflammation of the skin. PLoS Pathog. 2009;5(7):e1000527. https://doi.org/10.1371/journal. ppat. 1000527

PMid:19629174

27. Wasitaatmadja SM. Akne, erupsi akneiformis, rosasea, rinofima. [Acne, eruption acneiformis, rosacea, rhinophyma]. In: Djuanda A, Hamzah M, Aisah S, editors. Ilmu Penyakit Kulit Dan Kelamin. Dermatology and Venereology. Jakarta: Faculty of Medical, University of Indonesia; 2010.

28. Jorat MV, Tabrizi R, Kolahdooz, Akbari M, Salami M, Heydari ST, et al. The effects of coenzyme Q10 supplementation on biomarkers of inflammation and oxidative stress in among coronary artery disease: A systematic review and metaanalysis of randomized controlled trials. Inflammopharmacol. 2019;27:233-48. https://doi.org/10.1007/s10787-019-00572-x PMid:30758695

29. Zhang M, Dang L, Guo F, Wang X, Zhao W, Zhao R. Coenzyme $Q(10)$ enhances dermal elastin expression, inhibits IL-1a production and melanin synthesis in vitro. Int J Cosmetic Sci. 2012;34(3):273-9. https://doi. org/10.1111/j.1468-2494.2012.00713.x

PMid:22339577
30. Szmurło A, Kucharska A. Significance of diet and oral supplementation in acne vulgaris. EMJ Dermatol. 2016;4(1):904. https://dx.doi.org/10.5114\%2Fada.2016.59146 PMid:27279815

31. Addor FAS. Antioxidants in dermatology. Ana Brasi Dermatol. 2017;92(3):356-62. https://doi.org/10.1590/ abd1806-4841.20175697

PMid:29186248

32. Leyden J, Stein-Gold L, Weiss J. Why topical retinoids are mainstay of therapy for acne. Dermatol Ther. 2017;7(3):293304. https://dx.doi.org/10.1007\%2Fs13555-017-0185-2 PMid:28585191

33. Perihan $\mathrm{O}$, Ergul KB, Neslihan D, FilizA. The activity of adenosine deaminase and oxidative stress biomarkers in scraping samples of acne lesions. J Cosmetic Dermatol. 2012;11(4):323-8. https:// doi.org/11. 10.1111/jocd.12011.

34. Al-Shobaili HA, Alzolibani AA, Al Robaee AA, Meki AR, Rasheed Z. Biochemical markers of oxidative and nitrosative stress in acne vulgaris: Correlation with disease activity. Ann Clin Lab Sci. 2013;27(1):45-52. https://dx.doi. org/10.1002\%2Fjcla.21560

PMid:23325743 